\title{
Development and Validation of RP-UPLC Method for the Determination of Iloperidone, Its Related Compounds and Degradation Products in Bulk and Dosage Form*
}

Shashikant B. Landge, Sanjay A. Jadhav, Shrihari P. Vishwambar, Pavankumar V. Solanki, Saroj R. Bembalkar, Vijayavitthal T. Mathad\#

Research and Development, Megafine Pharma (P) Ltd., Nashik, India

Email: "vt.mathad@megafine.in, " drvtmathad@yahoo.co.in

Received 15 August 2014; revised 1 October 2014; accepted 20 October 2014

Copyright (C 2014 by authors and Scientific Research Publishing Inc.

This work is licensed under the Creative Commons Attribution International License (CC BY).

http://creativecommons.org/licenses/by/4.0/

c) (i) Open Access

\begin{abstract}
A rapid, specific, sensitive, and precise reverse-phase UPLC method developed for the quantitative determination of an atypical antipsychotic drug Iloperidone and its eight potential impurities in drug substances and drug products is described in this report. Chromatographic separation was achieved on a Waters Acquity UPLC ${ }^{\circledR}$ HSS C18 $(2.1 \mathrm{~mm} \times 100 \mathrm{~mm}, 1.8 \mathrm{micron})$ column thermostated at $35^{\circ} \mathrm{C}$ with a short runtime of $10 \mathrm{~min}$. Quantification is achieved with photodiode array detection at $225 \mathrm{~nm}$ over the concentration range of $0.03-0.15 \mu \mathrm{g} / \mathrm{mL}$. Forced degradation study was carried out under acidic, alkaline, oxidative, photolytic and thermal conditions to demonstrate the stability-indicating capability of the developed UPLC method. Comparison of system performance with conventional high-performance liquid chromatography is made with respect to analysis time, efficiency, and sensitivity. The method is validated according to the ICH guidelines and is applied successfully for the determination of Iloperidone in tablets.
\end{abstract}

\section{Keywords}

Iloperidone, UPLC, Degradation, RSD and Validation, Stability Indicating

\footnotetext{
*Megafine Publication Number: MF/016/2014.

\#Corresponding author.
}

How to cite this paper: Landge, S.B., et al. (2014) Development and Validation of RP-UPLC Method for the Determination of Iloperidone, Its Related Compounds and Degradation Products in Bulk and Dosage Form. American Journal of Analytical Chemistry, 5, 969-981. http://dx.doi.org/10.4236/ajac.2014.514104 


\section{Introduction}

Ultra Performance Liquid Chromatography (UPLC) has become promising high speed chromatographic separation technique in the field of pharmaceutical industry. UPLC offers substantial improvements on chromatographic resolution, speed and sensitivity analysis compared to conventional HPLC separation techniques. High efficiency and less run time are the two major advantages of this technology. It utilizes sub-2 mm particles for the stationary phase and saves time and reduces solvent consumption. These particles operate at elevated mobile phase linear velocities to affect dramatic increase in the efficiency [1] [2]. In the present work, this technology has been applied to the method development, validation, and assay determination of Iloperidone bulk drug.

Iloperidone, chemically designated as 1-[4-[3-[4-(6-fluoro-1,2-benzisoxazol-3-yl)-1-piperidinyl]propoxy]-3methoxyphenyl]ethanone belongs to the subclass of combined D2/5HT2A antagonism, with greater affinity for the 5HT2A receptor than D2 receptor antagonism and is approved by FDA in May-2009 for the acute treatment of schizophrenia in adults [3]. Iloperidone has been shown to act as an antagonist at all tested receptors. It was found to block the sites of noradrenalin ( $\alpha 2 \mathrm{C}$ ), dopamine (D2A and D3) and serotonin (5-HT1A and 5-HT6) receptors. In addition, pharmacogenomic studies identified single nucleotide polymorphisms associated with an enhanced response to Iloperidone during acute treatment of schizophrenia. It is considered an "atypical” antipsychotic because it displays serotonin receptor antagonism, similar to other atypical antipsychotics. The older typical antipsychotics are primarily dopamine antagonists. It is available in the market under the brand name Fanapt, Fanapta and Zomaril in the form of tablets for oral administration in seven different strengths, namely, 1 mg, $2 \mathrm{mg}, 4 \mathrm{mg}, 6 \mathrm{mg}, 8 \mathrm{mg}, 10 \mathrm{mg}$ and $12 \mathrm{mg}$ [4]-[9].

The analytical method for the determination of Iloperidone and its impurities in bulk and pharmaceutical dosage form is highly essential to monitor and control the impurities in the drug substances. Although many analytical techniques like gas chromatography (GC), capillary electrophoresis (CE), and liquid chromatography (LC) can be employed for the analysis, the most widely used technique is reverse phase liquid chromatography employing a non-polar stationary phase [10].

Extensive efforts have been found in literature towards the development of analytical method for the determination of Iloperidone and its related impurities in biological samples, bulk drug sample and in pharmaceutical dosage form. A literature survey also revealed that the analytical methods were available for the investigation of pharmacokinetics of Iloperidone where the content of Iloperidone individually and/or with its principal metabolite 4-[3-[4-(6-fluoro-l,2-benzisoxazol-3-yl)-l-piperidinyl]propoxy]-3-methoxy- $\alpha$-methylbenzenemethanol in human plasma was studied by liquid chromatography-mass spectrometry method [11] [12]. Mutlib et al. have reported that HPLC-NMR and HPLC-NMR-MS methods for the identification of in vivo and in vitro metabolites of Iloperidone [13]. Stability indicating HPLC method reported [14] for Iloperidone bulk drugs samples and pharmaceutical dosage forms has been found to be non-selective at our end. In addition, few other methods for the quantitative determination of Iloperidone in pharmaceutical dosage forms have also been reported [15]-[18]. However, these papers were restricted to the determination of Iloperidone and failed to discuss the details of processrelated impurities and degradation impurities formed under the stress conditions employed. Recently, we reported an efficient and industrial scale synthesis of Iloperidone [19] from our laboratory. During the synthesis of Iloperidone, we come across many process related impurities and some of them were captured in our prior report. To the best of our knowledge, none of the currently available analytical methods can separate all these related compounds and degradation products of Iloperidone drug substance. There is no pharmacopoeial reference available for analysis of bulk API or solid dosage form of Iloperidone. Furthermore, there is no cost and time effective method reported in the literature that can adequately separate Iloperidone from its impurities and degredants in bulk and pharmaceutical dosage form. Moreover, the analysis using LCMS, GC/MSD and LC-MS-MS is very expensive and delicate as compared to UPLC for routine quality control analysis. Hence, we felt the need for the development of a selective, fast, cost-effective and stability-indicating method using this advanced technique (UPLC) for the determination of Iloperidone and its impurities in bulk and pharmaceutical dosage form. The developed method was successfully validated according to the USP $<1225>$ Validation of Compendial Procedures and ICH guidelines Q2 (R1), Validation of Analytical Procedures: Text and Methodology [20] [21].

\section{Experimental}

\subsection{Materials and Reagents}

Samples of Iloperidone and its eight impurities viz., Imp-1, Imp-2, Imp-3, Imp-4, Imp-5, Imp-6, Imp-7, and 
Imp-8 (Figure 1) were received from synthetic laboratory, Megafine Pharma (P) Ltd., Nashik, India. HPLC grade ammonium dihydrogen orthophosphate and triethylamine AR grade were purchased from Merck, Mumbai, India. Acetonitrile, gradient grade was purchased from J.T. Baker, Mumbai, India. High purity deionised water was obtained from Millipore, Milli-Q (Bedford, MA, USA) purification system.

\subsection{Instrumentation and Operating Conditions}

Nexera UFLC system (Shimadzu Corporation Kyoto, Japan) equipped with quaternary gradient pump, auto sampler, column oven, and photodiode array detector was used for method development and method validation. The output signal was monitored and processed using LabSolutions version 5.53. The UPLC columns used during method development were Acquity UPLC ${ }^{\circledR}$ HSS C18 $(2.1 \mathrm{~mm} \times 100 \mathrm{~mm}, 1.8 \mathrm{micron})$, Acquity CSH Phenyl-hexyl (2.1 mm $\times 100 \mathrm{~mm}, 1.7$ micron), and Acquity ${ }^{\circledR}$ HSS Cyano $(2.1 \mathrm{~mm} \times 100 \mathrm{~mm}, 1.8$ micron). Acquity UPLC ${ }^{\circledR}$ HSS C18 $\left(2.1 \mathrm{~mm} \times 100 \mathrm{~mm}, 1.8\right.$ micron) column thermostated at $35^{\circ} \mathrm{C}$ was used for the separation. Mobile phase-A comprising phosphate buffer (aqueous solution of $5 \mathrm{mM}$ ammonium dihydrogen orthophosphate and $0.1 \%$ triethylamine) and mobile phase-B was comprising mixture of acetonitrile and methanol in the ratio of $80: 20 \mathrm{v} / \mathrm{v}$ were used. The flow rate and injection volume was $0.5 \mathrm{~mL} \cdot \mathrm{min}^{-1}$ and $2 \mu \mathrm{L}$ respectively. The analysis was carried out under the gradient conditions as time $(\mathrm{min}) / \mathrm{A}(\mathrm{v} / \mathrm{v}): \mathrm{B}(\mathrm{v} / \mathrm{v}) ; \mathrm{T}_{0.01} / 65: 35, \mathrm{~T}_{1.5} / 65: 35$,

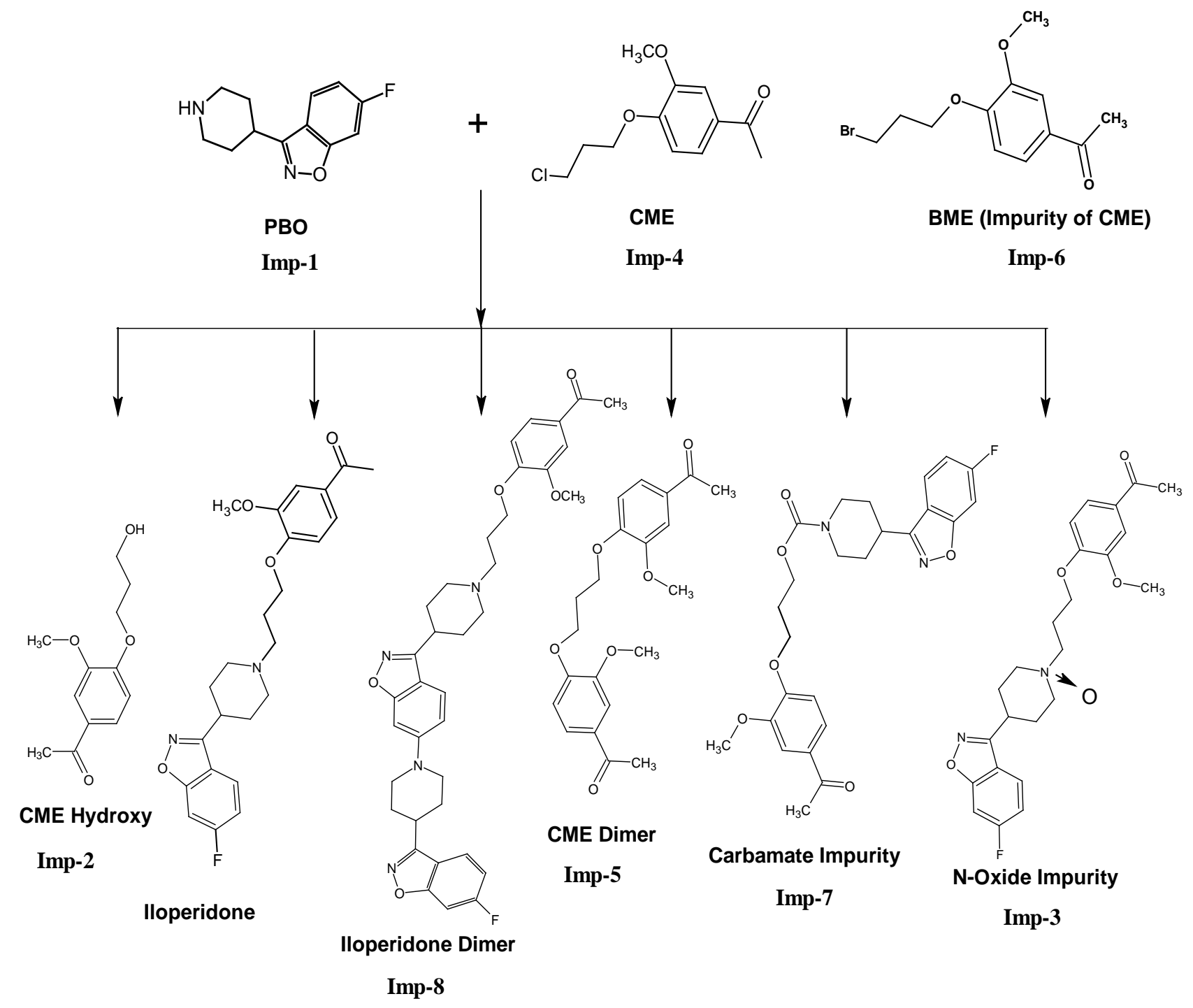

Figure 1. Process related impurities and degradation related impurities of Iloperidone. 
$\mathrm{T}_{5.0} / 35: 65, \mathrm{~T}_{7.0} / 35: 65, \mathrm{~T}_{8.0} / 65: 35$, and $\mathrm{T}_{10.0} / 65: 35$. The data was acquired at $225 \mathrm{~nm}$ for $10 \mathrm{~min}$ and processed by using LabSolutions version 5.53. For the analysis of forced degradation study, the photo diode array detector was set to scan from $200 \mathrm{~nm}$ to $400 \mathrm{~nm}$. The peak homogeneity was calculated in terms of peak purity.

\subsection{Preparation of Solutions}

The diluent used for the analysis was prepared using homogenous mixture of $700 \mathrm{~mL}$ of water and $300 \mathrm{~mL}$ acetonitrile. A solution of Iloperidone was prepared at concentration of $1000 \mu \mathrm{g} \cdot \mathrm{mL}^{-1}$ in diluent. Stock solutions of each impurity (Imp-1 to Imp-8) were prepared at concentration of about $150 \mu \mathrm{g} \cdot \mathrm{mL}^{-1}$ in diluent. These solutions were further diluted to prepare standard solution for quantification of impurities according to the specification limits $(0.15 \%)$ of each impurity.

Sample of formulation drug was prepared by powdering twenty tablets of Iloperidone, dissolving an equivalent of $25 \mathrm{mg}$ of active ingredient in diluent in a $25 \mathrm{~mL}$ volumetric flask and ultra sonicating for about 15 - 20 min. The volume was made up to the mark with the diluent, and filtered through Merck Nylon syringe filter having pore size $0.45 \mu \mathrm{m}$. The clear liquid was collected and used for the determination of related substances in the pharmaceutical dosage forms. This solution was ten times diluted for the assay determination in pharmaceutical dosage forms.

\subsection{Analytical Procedure}

Iloperidone with concentration of $1000 \mu \mathrm{g} \cdot \mathrm{mL}^{-1}$ was spiked with Imp-1, Imp-2, Imp-3, Imp-4, Imp-5, Imp-6, Imp-7 and Imp-8 at specification level i.e., $0.15 \%$ and the obtained solution was used as a system suitability mixture. $2 \mu \mathrm{L}$ each of blank preparation, system suitability mixture (SSM), 6 replicates of standard solution and test solution are injected and separately chromatographed under the given chromatographic conditions. Resolution condition of not less than 1.5 between Imp- 4 and Imp- 5 was set as system suitability parameter for SSM. The relative standard deviation of not more than $5.0 \%$ for areas obtained from six replicate injections of all impurities was used to verify the system precision.

\subsection{Procedure for Forced Degradation Study}

The forced degradation study was planned to investigate specificity and stability indicating property of the established method [22]-[24]. The API was deliberately stressed in solution state at acidic and alkaline pH, under oxidation conditions, in solid state at thermal and photolytic conditions. Solutions for degradation were prepared by dissolving the API in diluent at specification level i.e. $1000 \mu \mathrm{g} \cdot \mathrm{mL}^{-1}$ in diluent and then treating with conc. hydrochloric acid $\left(24 \mathrm{hr}\right.$ heating at $\left.110^{\circ} \mathrm{C}\right)$, with $5 \mathrm{~N}$ sodium hydroxide $\left(24 \mathrm{hr}\right.$ heating at $\left.110^{\circ} \mathrm{C}\right)$, and with $30 \%$ aqueous hydrogen peroxide ( $15 \mathrm{~min}$ at room temperature). The solutions after treatment were diluted with diluents up to the mark to desired concentration of $1000 \mu \mathrm{g} \cdot \mathrm{mL}^{-1}$ and were injected in the established method. For thermal degradation, the solid API was heated at $105^{\circ} \mathrm{C}$ for 7 days in calibrated oven. For photolytic degradation, the sample was exposed to UV source as per the ICH guidelines for 10 days. The treated samples were diluted with diluent to the desired concentration of $1000 \mu \mathrm{g} \cdot \mathrm{mL}^{-1}$ and injected in the established method. All the stressed samples are quantified for Iloperidone and impurities. Photodiode array detector was used to establish peak purity and thus the homogeneity of Iloperidone peak under every stress condition. Mass balance of the degraded samples was carried out to correlate the loss of a parent drug and the increase in the amount of degradation products.

\section{Results and Discussion}

\subsection{LC Method Development and Transfer to UPLC}

The present study was aimed to develop a chromatographic system capable of eluting and resolving Iloperidone, its process related and degradation related impurities (Imp-1 to Imp-8) in short run time which complies with the general requirement of system suitability. During HPLC method development initial trials were conducted for optimizing various parameters on the system suitability of the method. The parameter assessed include the detection wavelength, the type and quantity of organic modifier, the column, salt concentration, $\mathrm{pH}$ of mobile phase and column temperature. 
Preliminarily, the gradient HPLC method was developed for separation of Iloperidone and all its related substances, which was then transferred to UPLC. Generally, gradient elution mode is always preferred over the isocratic elution mode in order to achieve improved peak shape and resolution, and for elution of late-eluting (nonpolar) impurities. In-addition, C18 bonded phases are the most popular phases for HPLC/UHPLC because they offer good retention and selectivity for a wide variety of sample types. Additionally, they are perceived to be more rugged and reliable than other bonded phases. C18 bonded phases depend mainly on hydrophobic interactions (and occasionally shape selectivity) to achieve satisfactory separations. Although versatile, C18 phases offer a limited number of separation mechanisms and this may lead to less than optimum separations in some cases and complete lack of resolution of important peak pairs in others. Hence, during method development it was decided to use a gradient HPLC mode with C18 phase. The chromatographic separation was achieved on a Hypersil BDS C18 $(250 \times 4.6 \mathrm{~mm}), 5 \mu \mathrm{m}$ column at flow rate $1.0 \mathrm{~mL} / \mathrm{min}$. The column oven temperature was maintained at $35^{\circ} \mathrm{C}$.

Finally, satisfactory peak shape and the resolution of closely eluting potential impurity (Imp-4 and Imp-5) was achieved on a Hypersil BDS C18 column $(250 \times 4.6 \mathrm{~mm}$ and $5.0 \mu \mathrm{m}$ particle size), by using mobile phase consisting the mixture of phosphate buffer and acetonitrile. There was a good separation of Iloperidone from its known impurities, while it was found to be eluting at a higher retention time (around $16.5 \mathrm{~min}$ ) with a total run time of $45 \mathrm{~min}$. To reduce the run time, the gradient HPLC mode was switched over to a gradient UPLC mode with Acquity UPLC ${ }^{\circledR}$ HSS C18 $(2.1 \mathrm{~mm} \times 100 \mathrm{~mm}, 1.8 \mu)$ column. The response of Iloperidone and its related impurities were found to be adequate at $225 \mathrm{~nm}$. The basic chromatographic conditions, such as the stationary phase, solvents, and UV detection employed in HPLC, were taken into account while developing the new UPLC method. The detection wavelength, column temperature, and solvent used in HPLC were kept constant. The C18 stationary phase was chosen in order to have similar chemistry to that used in the HPLC. In UPLC, an Acquity UPLC $^{\circledR}$ HSS C18 $(2.1 \mathrm{~mm} \times 100 \mathrm{~mm}, 1.8 \mu)$ column was employed for the separation. The injection volume was set to $2 \mu \mathrm{L}$ from $20 \mu \mathrm{L}$, as used in HPLC. The flow rate was scaled to $0.5 \mathrm{~mL} / \mathrm{min}$. Using these condition, a satisfactory separation was achieved within 10 min by maintaining maximum back pressure at $9000 \mathrm{psi}$.

\subsection{Comparison Study of Chromatographic Performance}

Comparative data on chromatographic performance of HPLC and UPLC has been obtained by injecting a solution of system suitability. The performance parameters of both the systems are shown in Table 1. It is observed as compared to HPLC method the elution time of Iloperidone in UPLC was reduced from $17 \mathrm{~min}$ to $3 \mathrm{~min}$. The resolution and theoretical plates obtained for Iloperidone in UPLC show comparatively better separation efficiency than HPLC. Theoretical plates obtained for Iloperidone in gradient mode HPLC was obviously higher than UPLC. The typical chromatograms obtained from the final HPLC and the UPLC conditions are depicted in Figure 2 and Figure 3 respectively.

\subsection{Development of Chromatographic Conditions}

\subsubsection{Identification of Impurities}

All known impurities (Imp-1 to Imp-8) are spiked in Iloperidone at desired concentrations of $0.15 \%$ with respect to test concentration of $1000 \mu \mathrm{g} \cdot \mathrm{mL}^{-1}$ to confirm the retention times under the chosen chromatographic condi-

Table 1. A comparison of system performance of HPLC and UPLC for Iloperidone.

\begin{tabular}{ccc}
\hline Parameter & HPLC gradient & UPLC gradient \\
\hline Elution time (min) & 17.0 & 3.0 \\
Flow rate $(\mathrm{mL} / \mathrm{min})$ & 1.0 & 0.5 \\
Injection volume $(\mu \mathrm{L})$ & 20 & 2 \\
Run time (min) & 45 & 10 \\
Tailing factor & 2.04 & 1.38 \\
USP plate count & 156,013 & 101,857 \\
\hline
\end{tabular}




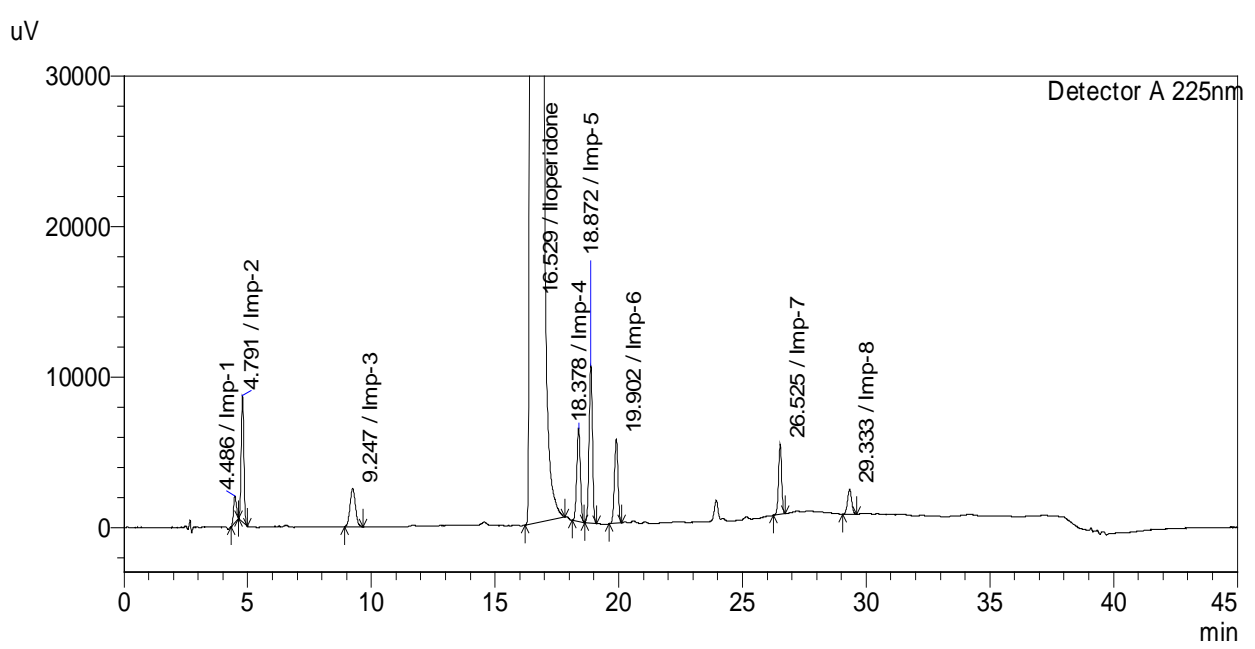

(a)

uV

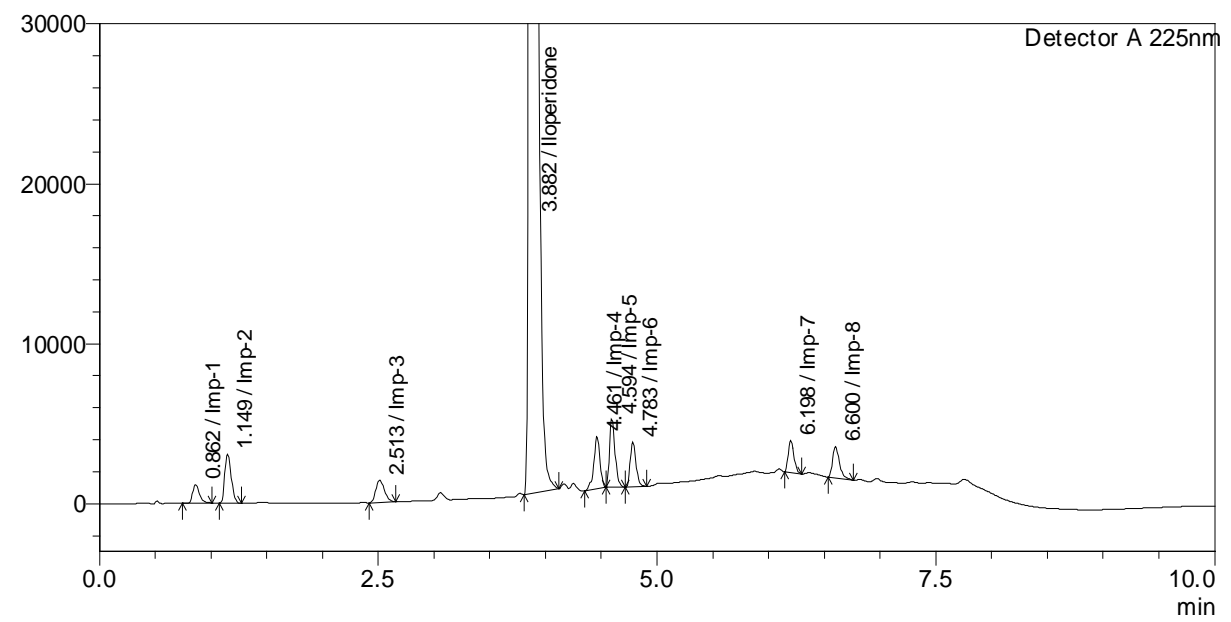

(b)

Figure 2. Comparison of the chromatograms of SST obtained from (a) HPLC and (b) UFLC.

tions. All the impurities were well resolved from each other. Among the identified impurities, Imp-1 and Imp-4 are the key starting materials in the process; Imp-2, Imp-5, Imp-7 and Imp-8 are the process related impurities, whereas Imp- 3 is process as well as degradation related impurity; Imp-6 is a carryover impurity from key starting material (CME) as shown in Figure 1.

\subsubsection{Optimization of UPLC Chromatographic Conditions}

The core objective of developing the UPLC method is to detect and determine the potential impurities present in Iloperidone bulk and pharmaceutical dosage form and to achieve the separation of all eight impurities (Imp-1 to Imp-8) along with the degradation products generated during stress studies. Various UPLC stationary phases like Acquity UPLC ${ }^{\circledR}$ HSS C18 $(2.1 \mathrm{~mm} \times 100 \mathrm{~mm}, 1.8$ micron$)$, Acquity CSH Phenyl-hexyl $(2.1 \mathrm{~mm} \times 100 \mathrm{~mm}$, 1.7 micron), and Acquity ${ }^{\circledR}$ HSS Cyano $(2.1 \mathrm{~mm} \times 100 \mathrm{~mm}, 1.8$ micron) were used during development. Mobile phase-A was prepared by using buffers like phosphate, sulphate and acetate with $\mathrm{pH}$ ranging over from 3.0 to 10.0 Organic modifiers like acetonitrile and methanol were evaluated as mobile phase-B. Satisfactory chromatographic separation was achieved on Acquity UPLC ${ }^{\circledR}$ HSS C18 column in terms of better resolution of peaks due to Iloperidone from impurities and degredants as well as better peak shape.

The typical retention times of Imp-1, Imp-2, Imp-3, Iloperidone, Imp-4, Imp-5, Imp-6, Imp-7 andImp-8 were about $0.86,1.15,2.51,3.82,4.46,4.59,4.78,6.20$ and 6.60 min, respectively (Figure 2), and the developed 


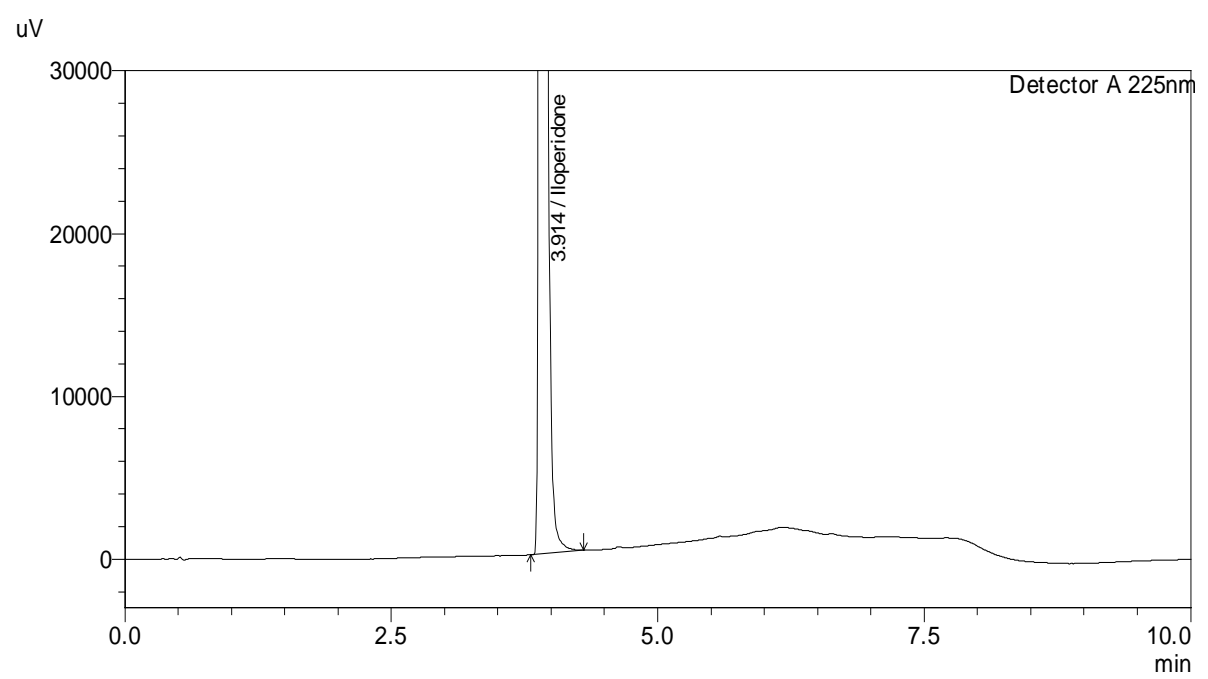

(a)

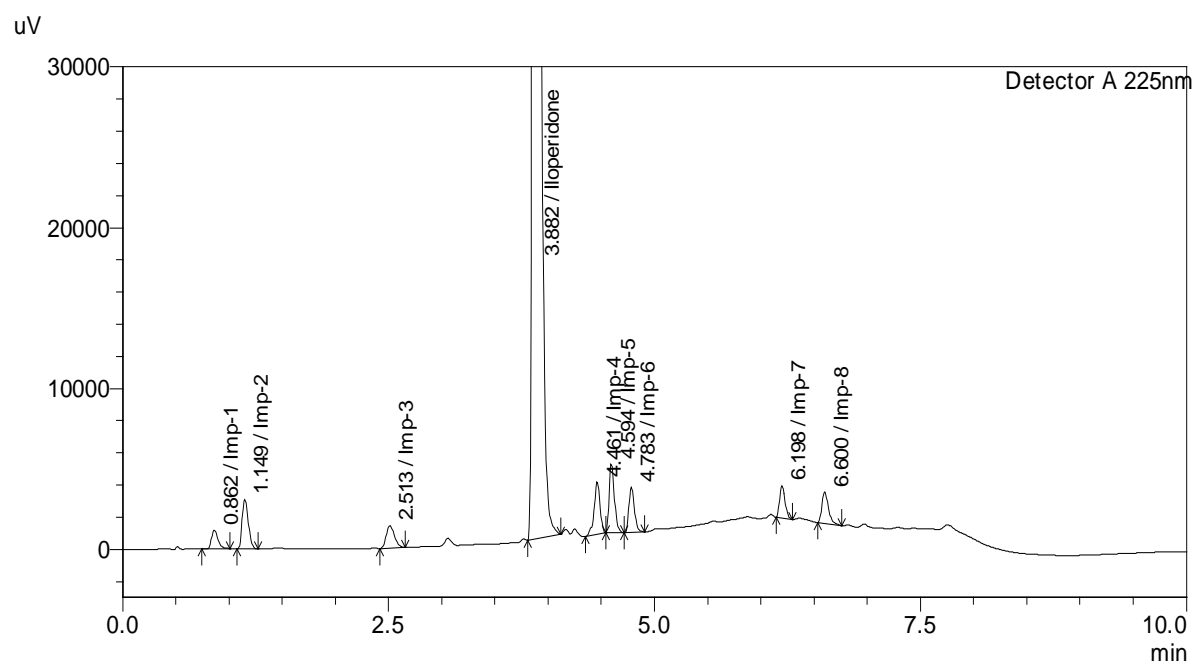

(b)

Figure 3. Typical UPLC chromatograms of (a) Iloperidone un-spiked test preparation; (b) Iloperidone spiked test preparation with known impurities (Imp-1 to Imp-8).

UPLC method was found to be specific for determination of Iloperidone and its impurities in bulk and pharmaceutical dosage form.

\subsubsection{System Suitability Criteria}

A system suitability test was defined based on the results obtained in several representative chromatograms. The column efficiency determined from the analyte peak $>20,000$, the tailing factor $<2.0$, and RSD for impurity areas in six replicate injection of system suitability solution was $<5.0 \%$. A resolution between peaks of Imp-4 and Imp-5, and Imp-5 and Imp-6 was $>1.5$ in SST solution. All the system suitability criteria's during validation the study and batch analysis study were within the acceptance limit. The results of system suitability are depicted in Table 2.

\subsection{Validation}

\subsubsection{Specificity (Selectivity)}

The data on forced degradation studies revealed that the degradation products were well separated from Iloperidone and the peak purity data of Iloperidone proved the homogeneity of the peak. Significant degradation was 
Table 2. System suitability test results.

\begin{tabular}{ccccccc}
\hline Compound & Capacity factor $(\mathbf{k})$ & Selectivity $(\boldsymbol{\alpha})$ & Resolution $\left(\mathbf{R}_{\mathbf{s}}\right)$ & Tailing factor $(\mathbf{T})$ Theoretical plates & RRT \\
\hline Imp-1 & 2.800 & 1.45 & - & 1.37 & 5755 & 0.75 \\
Imp-2 & 4.065 & 2.49 & 2.5 & 1.36 & 10,496 & 1.00 \\
Imp-3 & 10.117 & 1.57 & 10.6 & 1.28 & 33,660 & 2.19 \\
Iloperidone & 15.874 & 1.16 & 9.8 & 1.38 & 101,857 & 3.33 \\
Imp-4 & 18.487 & 1.03 & 5.2 & 1.19 & 195,423 & 3.85 \\
Imp-5 & 19.078 & 1.04 & 1.6 & 1.38 & 206,553 & 3.96 \\
Imp-6 & 19.887 & 1.31 & 1.8 & 1.29 & 215,924 & 4.12 \\
Imp-7 & 26.048 & 1.07 & 12.8 & 1.38 & 319,980 & 5.34 \\
Imp-8 & 27.774 & - & 3.4 & 1.29 & 324,691 & 5.68 \\
\hline
\end{tabular}

RRT (Relative retention time).

observed in acid and peroxide solution as shown in Figure 4. The mass balance is a process of adding together the assay value and the levels of degradation products to see how closely these add up to $100 \%$ of initial value with due consideration of the margin of analytical error. The mass balance of stressed samples was close to $100 \%$. Forced degradation study results are given in Table 3 .

\subsubsection{Linearity}

Linearity test solutions for related substance were prepared by diluting the impurity stock solution (as described in the section of Analytical Procedure) to the required concentrations. The solutions were prepared at six concentration levels from LOQ to $250 \%$ (LOQ, $0.75 \mu \mathrm{g} \cdot \mathrm{mL}^{-1}, 1.5 \mu \mathrm{g} \cdot \mathrm{mL}^{-1}, 2.25 \mu \mathrm{g} \cdot \mathrm{mL}^{-1}, 3.0 \mu \mathrm{g} \cdot \mathrm{mL}^{-1}$ and 3.75 $\mu \mathrm{g} \cdot \mathrm{mL}^{-1}$ ) with respect to the specification level of impurities. The data were subjected to statistical analysis using a linear-regression model; the regression equations and correlation coefficients are given in Table 4.

\subsubsection{Limits of Detection and Quantitation (LOD and LOQ)}

The limit of detection and limit of quantitation were determined for Iloperidone and for each of the related substances as per ICH Q2R1 guideline from the standard deviation of the peak areas and slope of linearity data. The values of LOD and LOQ for Imp-1, Imp-2, Imp-3, Imp-4, Imp-5, Imp-6, Imp-7, Imp-8 and Iloperidone were found to be in the range of $0.003 \%-0.015 \%$ and $0.001 \%-0.005 \%$ respectively. The calculated LOQ concentrations of all the components were verified for precision by injecting six individual preparations of Imp-1, Imp-2, Imp-3, Imp-4, Imp-5, Imp-6, Imp-7, Imp-8 and Iloperidone. The RSD of LOQ precision was in the range of $2.59 \%-8.74 \%$.These limits of quantification levels of the impurities were helpful for the process research work to control the impurities at the accepted level during the optimization of the process. The results were depicted in Table 4.

\subsubsection{Precision}

\section{1) System Precision}

System precision for related substances determination was verified by system suitability mixture (SSM), which was analyzed for six times and RSD of Iloperidone and all impurities peak areas were evaluated and found to be between $0.29 \%$ to $1.8 \%$.

2) Method Precision and Intermediate Precision

Precision of the method was studied for method precision and intermediate precision. Related substances method precision was demonstrated by analyzing six separate Iloperidone sample solutions that were prepared by spiking the related substances viz., Imp-1, Imp-2, Imp-3, Imp-4, Imp-5, Imp-6, Imp-7 and Imp-8 at specification level. The RSD $(n=6)$ for each related substance was evaluated. In the intermediate precision study, the similar procedure of method precision was carried out by a different analyst, using different mobile phase and diluent preparations and instrument on a different day with different lot of same brand column. The percentage relative standard deviation of the results for related substances method was evaluated and found to be $2.11 \%-3.14 \%$. 
uV

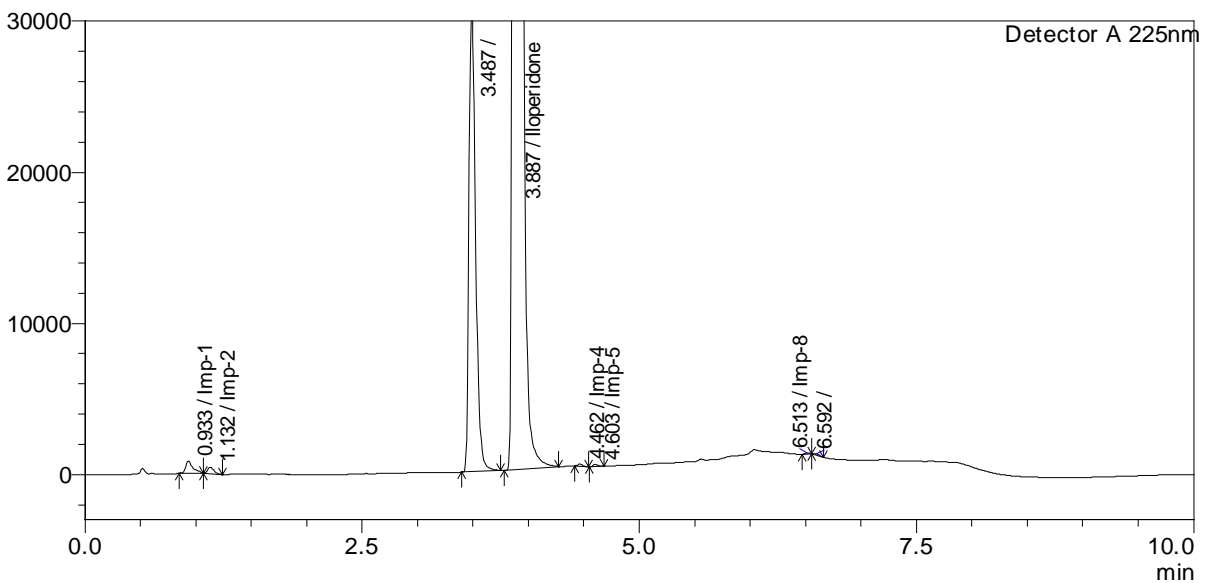

(a)

uV

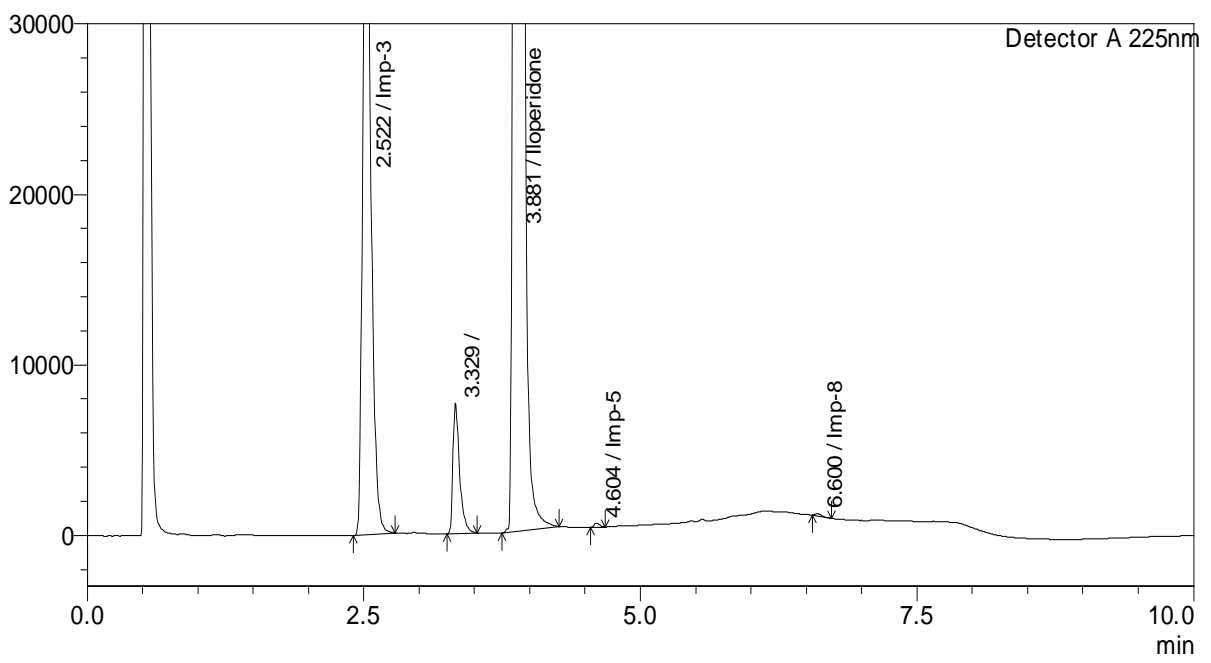

(b)

Figure 4. Typical UPLC chromatograms of forced degradation study: (a) Acid treated test sample; (b) Peroxide treated test sample.

Table 3. Forced degradation results.

\begin{tabular}{|c|c|c|c|c|}
\hline Stress condition & $\begin{array}{l}\text { \% assay of } \\
\text { Iloperidone }\end{array}$ & $\begin{array}{c}\% \text { of } \\
\text { degredants }\end{array}$ & Observation and mass balance & Peak purity \\
\hline Un-degraded & 99.1 & & - & 1000 \\
\hline $\begin{array}{c}\text { Acid hydrolysis } \\
\text { (Conc. } \mathrm{HCl}, 24 \mathrm{~h} \text { refluxed AT } 110^{\circ} \mathrm{C}-120^{\circ} \mathrm{C} \text { ) }\end{array}$ & 88.0 & 12.0 & $\begin{array}{l}\text { Major unknown degradation product } \\
(11.4 \%) \text { formed (Mass balance: } 98.9 \%)\end{array}$ & 995 \\
\hline $\begin{array}{c}\text { Base hydrolysis } \\
\left(5 \mathrm{M} \mathrm{NaOH}, 24 \mathrm{~h} \text { refluxed AT } 110^{\circ} \mathrm{C}-120^{\circ} \mathrm{C}\right)\end{array}$ & 100.2 & Nil & $\begin{array}{l}\text { No any known and unknown degradation } \\
\text { product formed (Mass balance: } 101.6 \% \text { ) }\end{array}$ & 995 \\
\hline $\begin{array}{c}\text { Oxidation } \\
\text { (30\% } \mathrm{H}_{2} \mathrm{O}_{2}, 15 \text { min. AT Room Temp.) }\end{array}$ & 83.9 & 16.1 & $\begin{array}{l}\text { Major known degradation impurity i.e. Imp-3 } \\
\text { formed (13.9\%). (Mass balance: } 98.8 \%)\end{array}$ & 1000 \\
\hline $\begin{array}{c}\text { Thermal } \\
\left(105^{\circ} \mathrm{C}, 7 \text {-days }\right)\end{array}$ & 99.9 & Nil & $\begin{array}{l}\text { No any known and unknown degradation } \\
\text { product formed (Mass balance: } 100.4 \% \text { ) }\end{array}$ & 990 \\
\hline Photolytic as per ICH & 100.5 & Nil & $\begin{array}{l}\text { No any known and unknown degradation } \\
\text { product formed (Mass balance: } 99.6 \% \text { ) }\end{array}$ & 1000 \\
\hline
\end{tabular}

Mass balance $=\%$ assay $+\%$ sum of all impurities $+\%$ sum of all degredants. 
Table 4. Linearity, limit of detection (LOD) and limit of quantitation (LOQ) data for Iloperidone and related substances.

\begin{tabular}{|c|c|c|c|}
\hline \multirow{2}{*}{ Component } & \multicolumn{2}{|c|}{ LOD /LOQ results } & \multirow{2}{*}{ Linearity } \\
\hline & LOQ $\mu \mathrm{g} / \mathrm{mL},(\% \text { w.r.t. })^{c}$ & LOD $\mu g / m L,(\% \text { w.r.t. })^{c}$ & \\
\hline Imp-1 & $0.144(0.014)$ & $0.018(0.004)$ & 0.9999 \\
\hline Imp-2 & $0.080(0.008)$ & $0.026(0.003)$ & 0.9995 \\
\hline Imp-3 & $0.049(0.005)$ & $0.016(0.002)$ & 0.9991 \\
\hline Iloperidone & $0.151(0.015)$ & $0.046(0.005)$ & 0.9993 \\
\hline Imp-4 & $0.034(0.003)$ & $0.011(0.001)$ & 0.9998 \\
\hline Imp-5 & $0.046(0.005)$ & $0.015(0.002)$ & 0.9991 \\
\hline Imp-6 & $0.086(0.010)$ & $0.028(0.003)$ & 0.9992 \\
\hline Imp-7 & $0.134(0.013)$ & $0.044(0.004)$ & 0.9995 \\
\hline Imp-8 & $0.152(0.015)$ & $0.046(0.005)$ & 0.9999 \\
\hline
\end{tabular}

${ }^{c} \mathrm{LOD}$ LOQ values are in \% with respect to test concentration of $1000 \mu \mathrm{g} / \mathrm{mL}$.

\subsubsection{Accuracy (Recovery)}

Accuracy of the method for all the related substances was determined by analyzing Iloperidone sample solutions spiked with all the related substances at four different concentration levels of LOQ, 50\%, 100\% and 150\% of each in triplicate at the specified limit. The recovery of all these related substances were found to be in-between the predefined acceptance criterion of $80.0 \%-120.0 \%$ and the data is given in Table 5 .

\subsubsection{Stability of Analytical Solution}

To determine the stability of sample solution, the sample solutions of Iloperidone spiked with related substances at specified level were prepared and analyzed immediately after preparation and after different time intervals up to $48 \mathrm{hrs}$, while maintaining the sample cooler temperature at about $25^{\circ} \mathrm{C}$ The results from these studies indicated that the sample solutions were stable at room temperature up to 48 hrs.

\subsubsection{Robustness}

To evaluate the robustness of the developed method, the chromatographic conditions were deliberately altered and the resolution between closely eluting peak pair i.e. Imp-3 and Imp-4 was evaluated. The flow rate of the mobile phase was $0.5 \mathrm{~mL} \cdot \mathrm{min}^{-1}$. To study the effect of flow rate on the resolution, the same was altered by 0.1 units i.e. from 0.4 to $0.6 \mathrm{~mL} \cdot \mathrm{min}^{-1}$. The effect of column temperature on resolution was studied at $32^{\circ} \mathrm{C}$ and $38^{\circ} \mathrm{C}$ instead of $35^{\circ} \mathrm{C}$. All the other mobile phase components were held constant as described above. In all the deliberate varied chromatographic conditions (flow rate and column temperature), the tailing factor of Iloperidone was less than 2.0 and the resolution between any two peaks was greater than 1.5 . There was a very minor variation in the resolution and tailing factor results observed in all the robustness conditions illustrating the robustness of the method.

\subsubsection{Application of the Method}

The analysis of commercial formulation sample and bulk drug sample indicated that the method is specific and selective for determination of related substances in the formulation and bulk drug samples (Table 6 and Table 7). The developed method is capable for quantitative analysis of Iloperidone in the bulk drug and in a pharmaceutical dosage form.

\section{Conclusion}

Simple, precise, robust, accurate and selective gradient RP-UPLC method to separate eight process related impurities, and degradation products of an atypical antipsychotic drug Iloperidone is described. The developed method was found to be capable of giving faster retention times and maintaining good resolution than that of 
Table 5. Accuracy data of related substances.

\begin{tabular}{|c|c|c|c|c|}
\hline \multirow{2}{*}{ Component } & \multicolumn{4}{|c|}{ Recovery results (Mean \% Recovery \pm \%RSD) } \\
\hline & $\begin{array}{c}\text { LOQ level; } \\
\text { amount (\%w/w) }\end{array}$ & $\begin{array}{c}50 \% \text { of specification level } \\
\text { amount }(\% \mathrm{w} / \mathrm{w})\end{array}$ & $\begin{array}{c}100 \% \text { of specification level }{ }^{\mathrm{b}} ; \\
\text { amount }(\% \mathrm{w} / \mathrm{w})\end{array}$ & $\begin{array}{l}150 \% \text { of specification level }{ }^{\mathrm{b}} ; \\
\text { amount }(\% \mathrm{w} / \mathrm{w})\end{array}$ \\
\hline Imp-1 & $103.33 \pm 0.19$ & $100.00 \pm 0.64$ & $96.08 \pm 1.19$ & $92.14 \pm 1.55$ \\
\hline Imp-2 & $105.11 \pm 0.58$ & $101.32 \pm 1.54$ & $100.66 \pm 0.89$ & $100.44 \pm 1.97$ \\
\hline Imp-3 & $106.67 \pm 1.99$ & $103.95 \pm 0.91$ & $101.96 \pm 0.66$ & $101.75 \pm 0.97$ \\
\hline Imp-4 & $113.33 \pm 2.14$ & $103.95 \pm 0.81$ & $101.32 \pm 0.87$ & $99.56 \pm 0.96$ \\
\hline Imp-5 & $103.33 \pm 1.21$ & $100.00 \pm 1.99$ & $101.21 \pm 1.14$ & $98.25 \pm 2.57$ \\
\hline Imp-6 & $110.00 \pm 1.56$ & $103.95 \pm 0.72$ & $101.32 \pm 0.37$ & $104.23 \pm 0.59$ \\
\hline Imp-7 & $116.67 \pm 2.11$ & $101.21 \pm 1.64$ & $100.54 \pm 1.89$ & $102.11 \pm 0.21$ \\
\hline Imp-8 & $95.26 \pm 2.11$ & $96.54 \pm 2.41$ & $97.05 \pm 1.05$ & $95.11 \pm 1.14$ \\
\hline
\end{tabular}

${ }^{\mathrm{a}} \%$ Recovery average of three determinations; ${ }^{\mathrm{b}} 0.15 \%$ of all related substances.

Table 6. Accuracy data of assay of Iloperidone in bulk drug and pharmaceutical form.

\begin{tabular}{ccc}
\hline & \multicolumn{2}{c}{ Recovery results (Mean \% Recovery ${ }^{\mathrm{a}}$ \%RSD) } \\
\cline { 2 - 3 } & Bulk drug & Pharmaceutical form $^{\circ}$ \\
\cline { 2 - 3 } $75 \%$ & $98.9 \pm 0.22$ & $98.9 \pm 0.67$ \\
$100 \%$ & $99.2 \pm 0.81$ & $98.7 \pm 0.85$ \\
$125 \%$ & $99.0 \pm 0.63$ & $98.5 \pm 0.51$ \\
$150 \%$ & $99.5 \pm 0.11$ & $99.0 \pm 0.44$ \\
\hline
\end{tabular}

${ }^{\mathrm{a}} \%$ Recovery average of three determinations.

Table 7. Results of formulated tablet analysis and bulk drug batches sample analysis.

\begin{tabular}{cccccc}
\hline \multirow{2}{*}{ Component } & \multicolumn{3}{c}{ Bulk drug sample batches } & \multicolumn{2}{c}{ Formulation sample } \\
\cline { 2 - 6 } & Batch No. 1 & Batch No. 2 & Batch No. 3 & Sample-1 & Sample-2 \\
\hline Imp-1 & ND & ND & ND & ND & ND \\
Imp-2 & ND & ND & ND & ND & ND \\
Imp-3 & ND & ND & ND & 0.01 & 0.02 \\
Iloperidone & 99.91 & 99.95 & 99.64 & 99.89 & 99.92 \\
Imp-4 & 0.01 & ND & 0.01 & ND & ND \\
Imp-5 & 0.01 & ND & ND & ND & ND \\
Imp-6 & ND & ND & ND & 0.01 & ND \\
Imp-7 & 0.03 & ND & ND & ND & ND \\
Imp-8 & ND & ND & ND & ND & ND \\
\hline
\end{tabular}

ND: Not detected. 
conventional HPLC. The developed method was validated to ensure the compliance in accordance with ICH guidelines and thus can be used for routine testing as well as stability analysis of Iloperidone drug substance and drug products. All statistical results (percentage, mean, R.S.D., percentage difference and recovery \%) were within the acceptance criteria.

\section{Acknowledgements}

The authors wish to thank the management of Megafine Pharma (P) Ltd., for supporting this work. The author is also thankful to colleagues in the division of Research and Development of Megafine Pharma (P) Ltd. for their cooperation in carrying out this work.

\section{References}

[1] Wren, S.A.C. and Tchelitcheff, P. (2006) Use of Ultra-Performance Liquid Chromatography in Pharmaceutical Development. Journal of Chromatography A, 1119, 140-146.

[2] Snyder, L.R., Kirkland, J.J. and Dolan, J.W. (1997) Introduction to Modern Liquid Chromatography.

[3] Weiden, P.J. (2012) Iloperidone for the Treatment of Schizophrenia: An Updated Clinical Review. Clinical Schizophrenia \& Related Psychoses, 34-44.

[4] Center for Drug Evaluation and Research (2009) NDA Approval Letter. Application Number 22-192. http://www.accessdata.fda.gov/drugsatfda_docs/nda/2009/022192s000_Approv.pdf

[5] Bishop, J.R. and Bishop, D.L. (2010) Iloperidone for the Treatment of Schizophrenia. Drugs, 46, 567-579.

[6] Arif, S.A. and Mitchell, M.M. (2011) Iloperidone: A New Drug for the Treatment of Schizophrenia. American Journal of Health-System Pharmacy, 68, 301-308.

[7] Nakano, M., Kitano, S., Nanri, M. and Kiniwa, M. (2011) Iloperidone, a Unique Histamine H2-Receptor Antagonist, Inhibits Distention-Induced Gastric Acid Secretion through an H2 Receptor-Independent Mechanism. European Journal of Pharmacology, 658, 236-241.

[8] Dewan, B. and Philipose, N. (2011) Iloperidone $10 \mathrm{mg}$ versus Rabeprazole $20 \mathrm{mg}$ in the Treatment of Patients with Heartburn-Dominant Uninvestigated Dyspepsia: A Randomized, Multicentric Trial. Gastroenterology Research and Practice, 2011, Article ID: 640685.

[9] Shimatani, T., Inoue, M., Kuroiwa, T., Xu, J., Nakamura, M., Tazuma, S., Ikawa, K. and Morikawa, N. (2006) Iloperidone, a Newly Developed Antiulcer Drug, Elevates Postprandial Intragastric pH and Increases Plasma Calcitonin Gene-Related Peptide and Somatostatin Concentrations in Humans: Comparisons with Famotidine. Digestive Diseases and Sciences, 51, 114-120. http://dx.doi.org/10.1007/s10620-006-3094-2

[10] Snyder, L.R., Kirkland, J.J. and Glajch, J.L. (1997) Practical HPLC Method Development. 2nd Edition. http://dx.doi.org/10.1002/9781118592014

[11] Wu, L.L., Zhang, Z.J., Tian, Y., Li, W., Xu, F.G., Chen, Y. and Wei, H.L. (2005) Determination of Lafutidine in Human Plasma by High-Performance Liquid Chromatography-Electrospray Ionization Mass Spectrometry: Application to a Bioequivalence Study. Journal of Mass Spectrometry, 40, 1637-1643. http://dx.doi.org/10.1002/jms.942

[12] Chen, W.D., Liang, Y., Li, H., Xiong, Y., Liu, X., Wang, G.J. and Xie, L. (2006) Simple, Sensitive and Rapid LC-ESI-MS Method for the Quantitation of Iloperidone in Human Plasma-Application to Pharmacokinetic Studies. Journal of Pharmaceutical and Biomedical Analysis, 41, 256-260. http://dx.doi.org/10.1016/j.jpba.2005.10.008

[13] Mutlib, A.E., Strupczewski, J.T. and Chesson, S.M. (1995) Application of Hyphenated LC/NMR and LC/MS Techniques in Rapid Identification of in Vitro and in Vivo Metabolites of Iloperidone. Drug Metabolism and Disposition, 23, 951-964.

[14] Mandpe, L.P. and Pokharkar, V.B. (2011) Stress Degradation Studies on Iloperidone and Development of a Stability Indicating HPLC Method for Bulk Drug and Pharmaceutical Dosage Form. Der Chemica Sinica, 2, 230-239.

[15] Sumithra, M., Sundaram, P.S. and Srinivasulu, K. (2011) Analytical Method Development and Validation of Iloperidone in Tablet Dosage form by RP-HPLC. International Journal of ChemTech Research, 3, 1403-1407.

[16] Chhalotiya, U.K., Bhatt, K.K., Shah, D.A. and Patel, J.R. (2012) Liquid Chromatographic Method for the Quantification of Antipsychotic Agent Iloperidone in Pharmaceutical Formulation. ISRN (International Scholarly Research Network) Analytical Chemistry, 2012, Article ID: 963276.

[17] Manjula Devi, A.S. and Ravi, T.K. (2012) Validation of UV Spectrophotometric and HPLC Methods for Quantitative Determination of Iloperidone in Pharmaceutical Dosage Form. International Journal of PharmTech Research, 4, 576581.

[18] Saravanan, G., Yunoos, M. and Shahanaz, S.K. (2013) A Validated Reverse Phase High Performance Liquid Chroma- 
tographic Assay Method for the Estimation of Iloperidone in Bulk and Commercial Tablet Dosage Form. Journal of Chemical and Pharmaceutical Research, 5, 506-511.

[19] Solanki, P.V., Uppelli, S.B., Pandit, B.S. and Mathad, V.T. (2014) Improved and Efficient Process for the Production of Highly Pure Iloperidone: A Psychotropic Agent. Organic Process Research and Development, 18, 342-348. http://dx.doi.org/10.1021/op400335p

[20] The United States Pharmacopeia (2009) Validation of Compendial Methods. 36th Edition (USP 36), Rockville.

[21] International Federation of Pharmaceutical Manufactures \& Associations (IFPMA) (1996) Validation of Analytical Procedure. International Conference on Harmonization (ICH), Methodology Q2(R1), Geneva.

[22] Ruan, J., Tattersall, P., Lozano, R. and Shah, P. (2006) The Role of Forced Degradation Studies in Stability Indicating HPLC Method Development. American Pharmaceutical Review, 9, 46-53.

[23] Bakshi, M. and Singh, S. (2002) Development of Validated Stability-Indicating Assay Methods-Critical Review. Journal of Pharmaceutical and Biomedical Analysis, 28, 1011-1040. http://dx.doi.org/10.1016/S0731-7085(02)00047-X

[24] Carstensen, J.T. and Rhodes, C.T. (2000) Drug Stability Principles and Practices. 3rd Edition, Marcel Dekker, New York. 
Scientific Research Publishing (SCIRP) is one of the largest Open Access journal publishers. It is currently publishing more than 200 open access, online, peer-reviewed journals covering a wide range of academic disciplines. SCIRP serves the worldwide academic communities and contributes to the progress and application of science with its publication.

Other selected journals from SCIRP are listed as below. Submit your manuscript to us via either submit@scirp.org or Online Submission Portal.
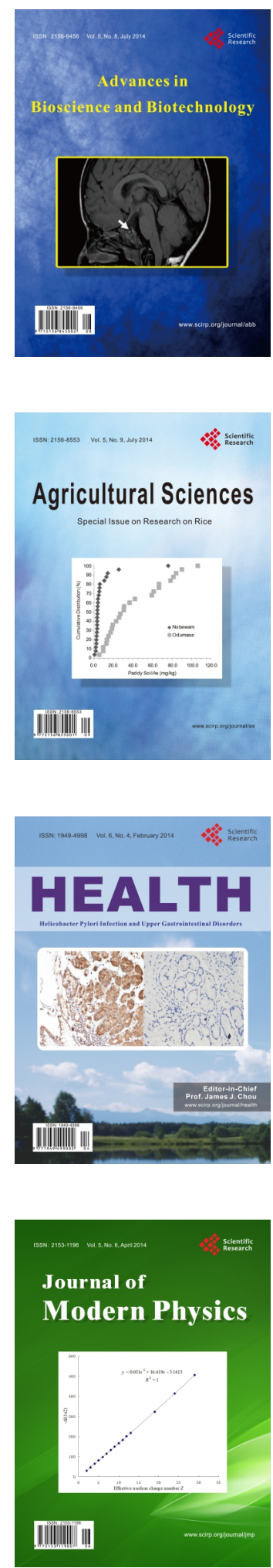
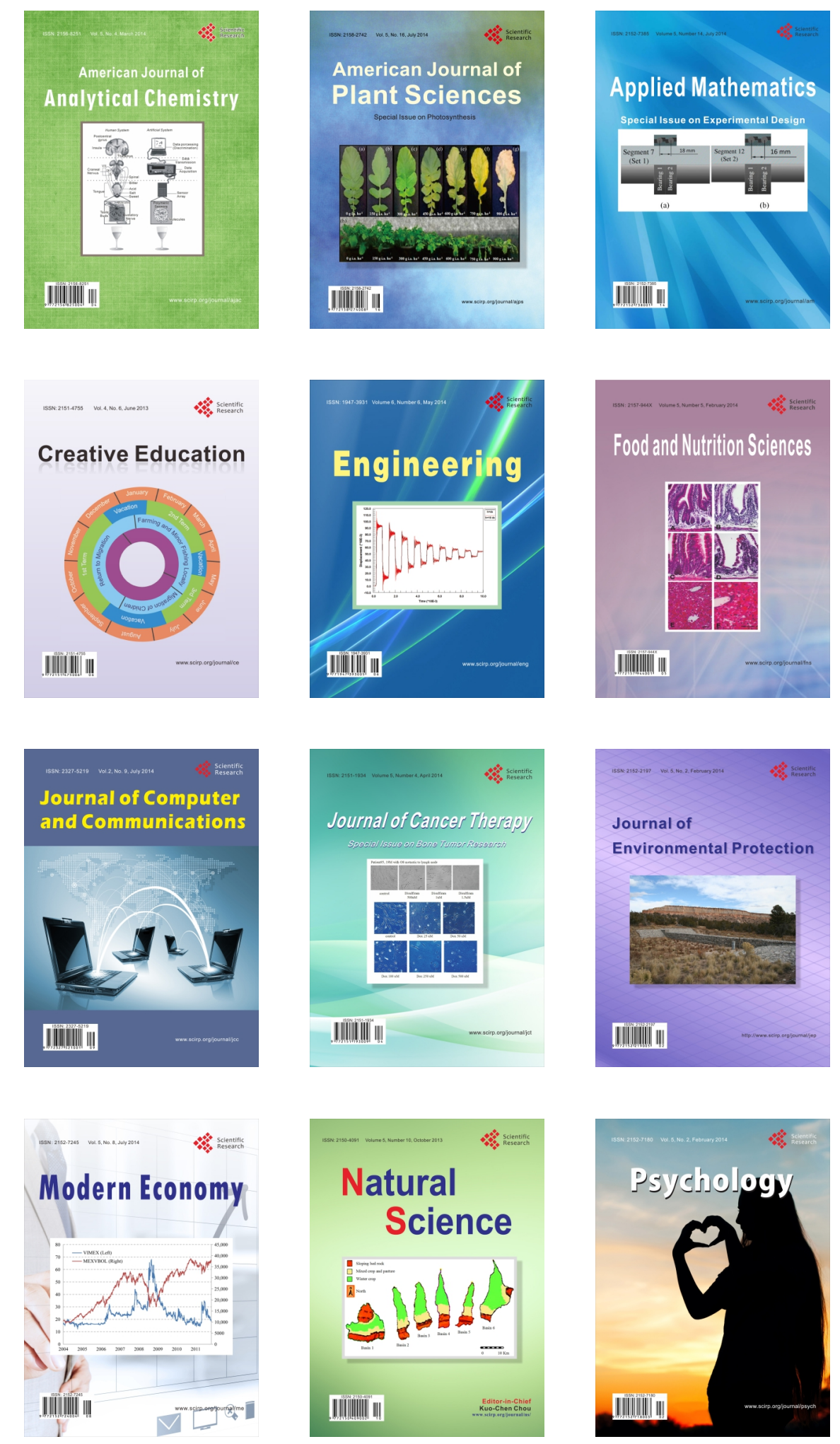